\title{
Disturbances-based plan of delineating protected area's buffer zone: A case study in Masigit Kareumbi Mountain, West Java, Indonesia
}

\author{
ELHAM SUMARGA ${ }^{1, \bullet}$, ICHSAN SUWANDHI ${ }^{1}$, HAIRATUNNISA ${ }^{2}$, DWI SUSILOWARDANI ${ }^{2}$, \\ ADENNA YUSKA NURRAHMAN ${ }^{2}$, ASHMA SADIDA ${ }^{2}$ \\ ${ }^{1}$ School of Life Sciences and Technology, Institut Teknologi Bandung. Jl. Ganesa 10, Bandung 40132, West Java, Indonesia. Tel./fax.: +62-22-2500935, \\ vemail: elham@sith.itb.ac.id \\ ${ }^{2}$ Forestry Engineering Program, School of Life Sciences and Technology, Institut Teknologi Bandung. Jl. Letjen Purn. Dr. (HC) Mashudi No.1, \\ Jatinangor, Sumedang 45363, West Java, Indonesia
}

Manuscript received: 27 July 2021. Revision accepted: 28 October 2021.

\begin{abstract}
Sumarga E, Swandhi I, Hairatunnisa, Susilowardani D, Nurrahman AY, Sadida A. 2021. Disturbances-based plan of delineating protected area's buffer zone: A case study in Masigit Kareumbi Mountain, West Java, Indonesia. Biodiversitas 22: 51155122. The harmony between ecosystems and people, particularly those who live around and inside protected areas, is a key factor for the success of ecosystem protection. This subsequently will ensure the maintenance of ecosystem capacity in providing different types of services. Unfortunately, human activities are still commonly linked to different types of disturbances inside protected areas. This study aims to spatially analyze the anthropogenic disturbances inside a protected area, with a case study in Mount Masigit Kareumbi Protected Area, Indonesia. Two types of disturbances, which can be directly and indirectly related to human intervention, are analyzed, i.e., fires and encroachment for agricultural purposes. This study used Maximum Enthropy (MaxEnt) to analyze the risk of forest fire, while the encroachment was analyzed based on a combination of satellite image interpretation and direct field observation. Fire risk modeling performed well with a mean AUC of 0.98, estimating high fire risk (fire probability more than 0.5) distributed in about 109 ha area inside the Mount Masigit Kareumbi Protected Area. This study also identified about 428 ha of forest encroachment inside the protected area. This study further used the spatial information of the disturbances to determine the priority for selecting and designing areas for buffer zone development.
\end{abstract}

Keywords: Conservation area, ecosystem protection, forest fires, forest encroachment, spatial planning

\section{INTRODUCTION}

There has been an increasing awareness of the critical role of protected areas in safeguarding the remaining biodiversity. This is particularly prominent for countries or regions experiencing high pressure of biodiversity loss such as Indonesia. Indonesia is recognized as a mega biodiversity country (Cleary and DeVantier 2019; Convention on Biological Diversity 2021), but on the other hand, has a long list of species that are threatened with extinction (Convention on Biological Diversity 2021). Indonesia has 794 animal species (including 564 birds, 137 mammals and 37 reptiles) and 127 plant species that are categorized under extinction risk and currently protected by Indonesian law (Indonesian Ministry of Environment and Forestry 2018).

In total, 554 protected areas have been established by Indonesian government with a total area of 27.1 million ha. The protected areas include 54 national parks that cover around 16.2 million ha and hundreds of other types of protected areas such as nature reserves, wildlife santuary, and game reserves (Indonesian Ministry of Environment and Forestry 2020). The protected areas are managed for three main purposes, i.e. to protect life support system, particularly hydrological system, to conserve biodiversity, and to sustainably utilize biological resources, particularly in the form of ecotourism.
Effective management of protected area requires support from stakeholders, in particular from local communities living inside and around protected area. Unfortunately, in many cases, different types of disturbance inside protected areas in Indonesia are still commonly linked to human activities (Brun et al. 2015; Cleary and DeVantier 2019). The disturbances that commonly take place in Indonesian protected areas include forest fire, forest encroachment, illegal logging and illegal poaching (Johnson et al. 2015; Siswanto 2017; Kahler 2018).

Development of buffer zone is often taken as an option to protect ecosystem inside protected areas against external pressures, particularly the risk of anthropogenic disturbances, and at the same time to provide benefits to local people (Sayer 1991). Buffer zone is commonly established to support ecosystem protection by providing extra area where the interaction between protected area and local community can be buffered (Bamford et al. 2014; Bhusal 2014; Mashapa et al. 2021). Resource utilization by local people can be localized inside buffer zone (Nguyen et al. 2019; Duong et al. 2021), hence the potential disturbances from human activities can be prevented. On the other hand, buffer zone can also provide extra habitat for wild animals (Jotikapukkana et al. 2010; Paolino et al. 2016), hence the potential damages caused by wild animals to local community can be minimized. 
One of the critical aspects in establishing buffer zone is selection of the best location for the buffer zone. Different studies have analyzed the use of different approaches in selecting and designing area for buffer zone of protected area. Alexandre et al. (2010) used a landscape species concept to design the buffer zone, using the information on the minimum area requirement for population viability of a selected wildlife species to define the size of buffer zones around protected area. In a more general context, Guevara and Laborde (2008) proposed a centrifugal model for biosphere reserve zoning, where the buffer zone should be established between the core area and the transition zone, and should function as a connector that facilitate the movement of species from the core area. Liu and Li (2008) used a habitat suitability approach for protected area's zoning design that considered both natural landscape factors and anthropogenic disturbance factors.

In the context of mitigation of ecosystem disturbances due to human activities, buffer zone should be established around the border of protected area where the high risk of anthropogenic disturbances exists. This study proposes a framework for development of buffer zone of protected area using spatial information of anthropogenic disturbances. This study aims to spatially analyze the anthropogenic disturbances inside a protected area as a basis for selecting the best sites for buffer zone development. Two types of disturbances that can be linked to human activities were analyzed, i.e. forest fire and encroachment for agricultural purposes. This study also shows how the disturbances-based buffer zone establishment can be further used to develop specific design of vegetation structure inside the buffer zone in response to specific disturbance encountered.
This study selects Masigit Kareumbi Mountain Protected Area (MKMPA), West Java, Indonesia as the study area, where evidences on anthropogenic disturbances took place in different places in this protected area. Management of the MKMPA currently still deal with big challenges in regard to finding the best solution for the human-caused problems. This study is then highly in line with the efforts to formulate a mutually beneficial relationship between protected area and local community, which can be implemented both in MKMPA and other protected areas dealing with similar problems.

\section{MATERIALS AND METHODS}

\section{Study area}

The MKMPA is a protected area in the middle of West Java province, Indonesia. Figure 1 presents the geographical information about the protected area. The MKMPA covers area of 12,470 ha with the highest elevation of 1763 meters above sea level. Most areas of the MKMPA are still covered by forests (90\%). There are two settlement areas (enclaves) inside the protected area, with a total area of 25 ha. The MKMPA is specifically designated as a game reserve, one of the protected area types in Indonesia, but up till now the legal hunting activity still could not be implemented in the protected area. The main conservation programmes of the MKMPA are focused on general conservation purposes such as biodiversity conservation and ecosystem services protection, particularly in the form of carbon sequestration and hydrological services.

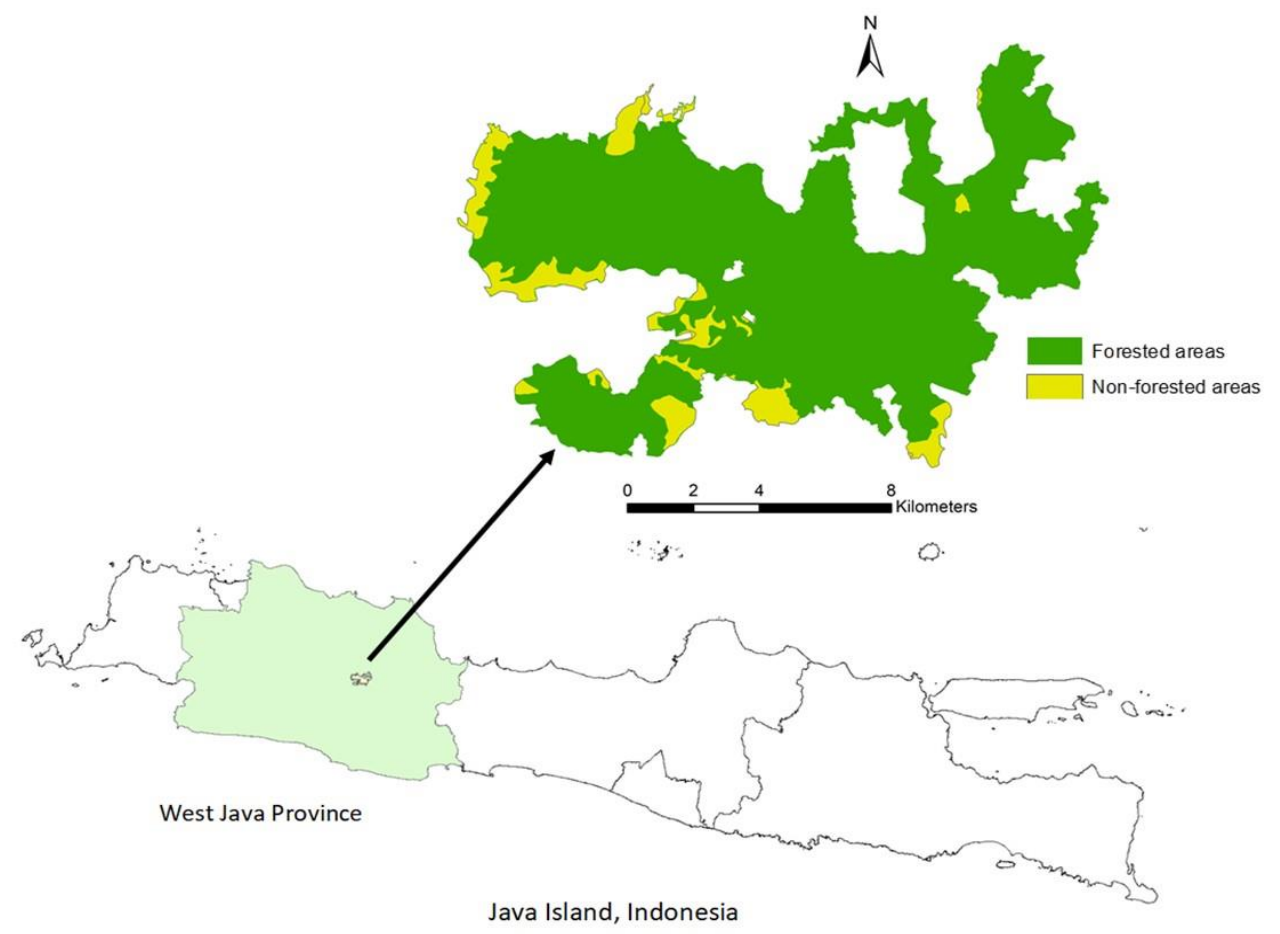

Figure 1. Geographical location and forest cover of the Mount Masigit Kareumbi Protected Area, West Java, Indonesia 


\section{Data collection and analysis}

This study analyzed two anthropogenic disturbances inside a protected area, i.e. forest fire and encroachment for agricultural purposes. The spatial information of the disturbances was then integrated to formulate the selection and design of buffer zone. The procedures of data collection and analysis for this study are described below.

\section{Forest fire risk analysis}

We used the Maximum Entropy (Maxent) version 3.3.3 (Phillips 2017) for mapping the risk of forest fire. Maxent requires two main inputs, i.e., presence data as training points, and environmental variables as predictors. We used 26 fire spots found in the MKMPA in 2015 as the presence data of forest fire. We visited the location of the fire spots to confirm the post-fire evidence and to observe the current vegetation condition. For environmental variables, we used Normalized Difference Vegetation Index (NDVI) generated from Sentinel 10 satellite image 2017, annual precipitation, elevation, slope, aspect, distance from roads, distance from settlements, distance from rice field, and distance from perennial crop area. We used annual precipitation data provided by WorldClim with a spatial resolution of around $1 \mathrm{~km}$ (30 arc seconds). For elevation data, we used the Digital Elevation Model (DEM) from the Shuttle Radar Topography Mission (SRTM) with a spatial resolution of $90 \mathrm{~m}$. We used all default basic settings of MaxEnt, except for the random test percentage (set to 30\%) and the replicates (set to 15). In addition, we used the logistic format as the representation of probabilities used in writing output grids. Among several measures that are commonly used to analyze the performance of MaxEnt, the area under receiver operating characteristic (ROC) curve (AUC) was used to indicate the model accuracy in this study. The AUC value ranges from 0.5 to 1 , where a higher AUC indicates a better model performance.

\section{Forest encroachment analysis}

Forest encroachment in this study was ascribed to the agricultural practices inside the protected area. The encroachment inside the MKMPA was mapped by a combination of visual interpretation of a satellite image and field survey to the encroached area. We used Landsat OLI 8 image 2015 and identified the encroached areas using onscreen digitizing method (Decker 2001) based on information collected from field survey. In addition, the encroached areas were also visited to collect data from local farmers and to describe the agricultural practices in the encroached areas.

\section{Selection and design of buffer zone}

Selection of area for buffer zone development was based on the spatial information of forest fire and forest encroachment. In response to the types of disturbances used in this study, two types of buffer zones were developed, i.e. fire prevention zone and encroachment prevention zone. The areas inside the MKMPA (with a width of 600 meters from the border of the protected area) with high risk of forest fire (the probability of fire $>0.5$ ) were selected as fire prevention zone. All encroached areas, distributed around the border of the protected area, were set as encroachment prevention zone. These approaches were in line with the common considerations used in selecting areas for a protected area's buffer zones, i.e areas around the border of protected area that can reduce the potential disturbances derived from human activities (e.g. Martin and Piatti 2009; Alexandre et al. 2010). Design of vegetation structure inside the buffer zones comprised of two main analyses, i.e. the selection of vegetation species and the layout of the selected species.

\section{RESULTS AND DISCUSSION}

\section{Fire risk}

This study used the 2015 fire evidence in the MKMPA, where fire incidences were distributed in 26 sites during October-November 2015. Field visit was conducted in 2018 to observe the post-fire condition, particularly the current vegetation structure. In terms of land cover, most of the fire spots were distributed in shrub areas (69\%), and the rest were dispersed in pine forest $(20 \%)$ and mixed forest $(11 \%)$. Figure 2 represents the general view of a post-fire site, acquired by an unmanned aerial vehicle (Phantom 4 Pro drone) that was equipped with a 1-inch 20 megapixel camera.

From vegetation survey in the post-fire sites, this study found 11 tree species (dominated by Pinus merkusii, Trema orientalis, Visenia umbellata, Schima wallichii, and Homalanthus populneus), seven shrub species (dominated by Lantana camara, Austroeupatorium inulifolium and Clidemia hirta) and 12 herb species (dominated by Imperata cylindrica, Ageratina riparia and Polygala paniculata).

MaxEnt modeling using nine environmental predictors resulted in a fire risk distribution as shown in Figure 3. The modeling performed well, indicated by a mean AUC of 0.99 for training data and 0.98 for testing data. By classifying the fire risks into five classes (with an equal interval of fire probability), this study found that the areas with high and very high fire risk only cover about $0.89 \%$ of the MKMPA area. Most of the MKMPA areas (about 96\%) have a shallow fire risk. The relationship between fire risk and four variables that represent human activities (distance to road, distance to settlement, distance to plantation, and distance to rice field) are presented in Figure 4.

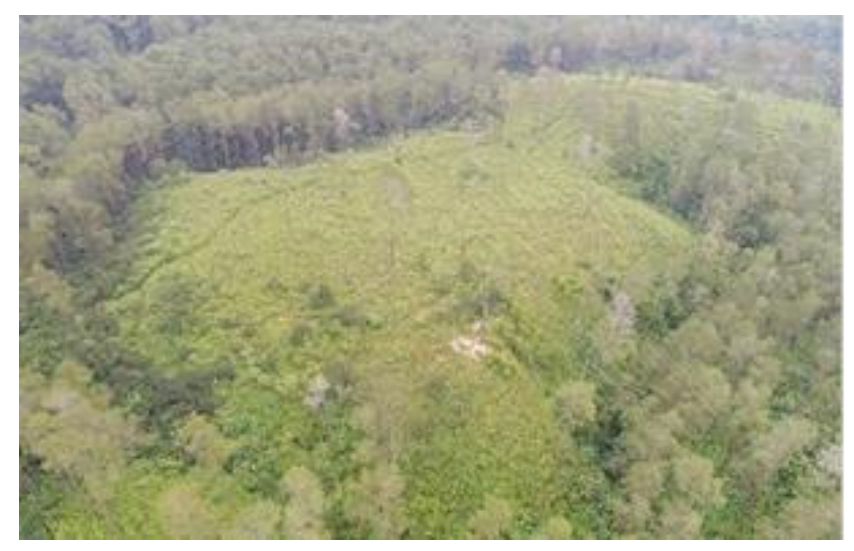

Figure 2. One of the post-fire areas in the MKMPA, Indonesia 


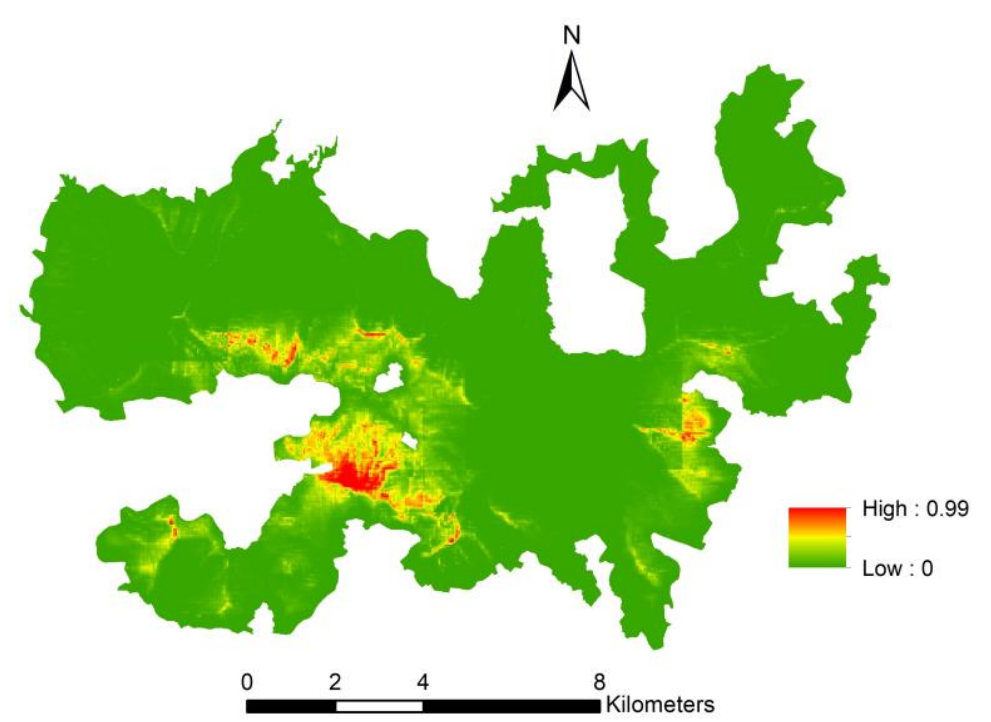

Figure 3. Fire risk distribution inside the MKMPA, West Java, , Indonesia

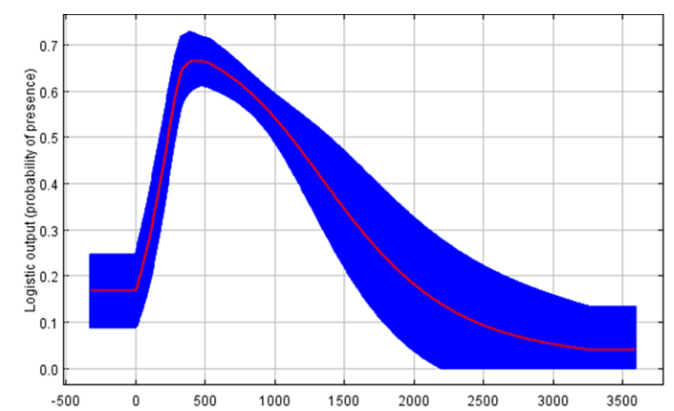

(a)

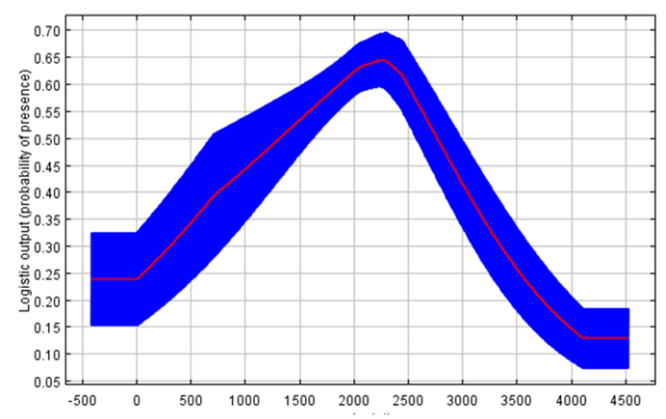

(c)

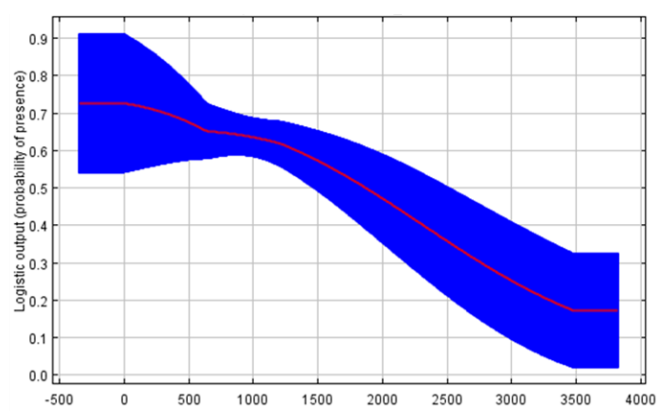

(b)

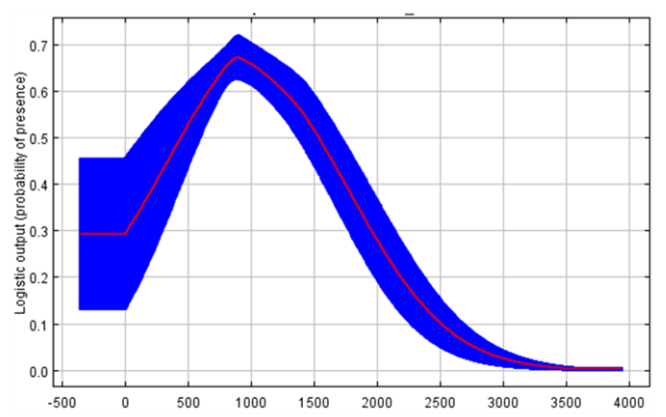

(d)

Figure 4. Curves of fire risk probability in response to four variables representing human activities: A. Distance to road, B. Distance to settlement, C. Distance to plantation, D. Distance to rice field

Figure 4 shows a reasonable relationship between fire risk and the four variables. By using a fire risk threshold of 0.5 , fire will potentially take place in areas with a distance interval of $300 \mathrm{~m}$ to $1200 \mathrm{~m}$ from road, $0 \mathrm{~m}$ to $1800 \mathrm{~m}$ from settlement, $1300 \mathrm{~m}$ to $2800 \mathrm{~m}$ from plantation, and $\sim 480 \mathrm{~m}$ to $1550 \mathrm{~m}$ from rice field. In terms of distance to road, fire risk tends to sharply increase from 0 to $400 \mathrm{~m}$ and steadily decreases afterward. In terms of distance to plantation and rice field, there is a quite similar fire risk pattern, which gradually increases from $0 \mathrm{~m}$ to the distance with the highest risk $(2300 \mathrm{~m}$ from plantation and $800 \mathrm{~m}$ from rice field) and gradually decreases afterward. The distance shows a different pattern to settlement. Starting from the distance of $0 \mathrm{~m}$, fire risk tends to decrease following the increase of distance continuously. In general, the four response curves show that high fire risk tends to 
distribute in areas with relatively close distance to several places representing human activities. This finding aligns with the common characteristics of Indonesian forest and land fire, which can be linked to human activities (Medrilzam et al. 2013; Sumarga 2017).

\section{Forest encroachment}

This study identified about 428 ha of forest encroachment inside the MKMPA (about $3.4 \%$ of the protected area). Figure 5 presents the general view of an encroached area in the form of expansion of agricultural area inside the protected area.

Based on field observation and interview with local farmers performing agricultural production inside the MKMPA, this study found that the farmers usually cultivated seasonal crops in the encroached areas for monetary reasons, without fully understanding that their cultivation was illegal. This was noted to be common for many cases of forest encroachments inside protected areas in Indonesia (Supriatna et al. 2020; Knott et al. 2021).

The main considerations for farmers in selecting area for the cultivation were the close distance to their settlement and the availability of water sources to irrigate their crops. Figure 6 presents the map of the encroached areas inside the MKMPA, which are distributed around the protected area border. The encroached areas were adjacent to 18 villages around and inside the protected area. The most common problems farmers encountered were pest attacks and decrease in soil fertility. In some cases, farmers abandoned their infertile land and cleared new places inside the protected area for crop production.

\section{Selection and design of buffer zone}

Based on the maps of fire risk and forest encroachment, the priority area for development of buffer zone in response to the two types of disturbances can be specified. Figure 7 presents the selected area proposed for buffer zone development in the study area. The buffer zone consists of two zones: fire prevention zone (109 ha) and encroachment prevention zone (384 ha). About 44 ha of encroached areas have high fire risk, and were categorized as a fire prevention zone.

The fire prevention zone is designated as a firebreaks area. Shrubs and agricultural areas in this zone will be the main target for reforestation with specific purpose for fire prevention. One of the critical aspects of reforestation is the selection of tree species. This study considers the following characteristics for the selection: relatively resistant to fire, local species, fast growing species, evergreen, requiring less maintenance, and wide tree canopy. Based on this consideration, this study selected seven tree species (Table 1) to develop the fire prevention zone.

The design of tree composition and configuration for the fire prevention zone, with a sample layout area of $20 \times$ $20 \mathrm{~m}^{2}$, is presented in Figure 8.

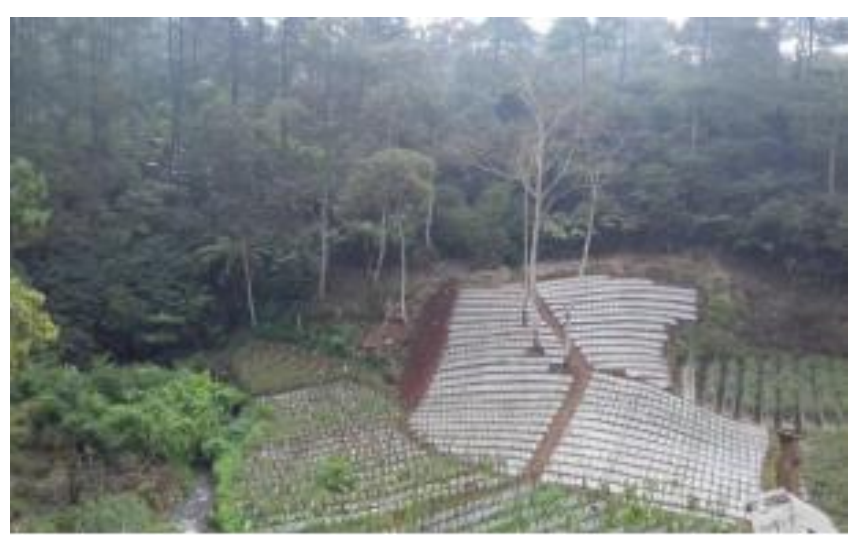

Figure 5. One of the encroached areas inside the MKMPA

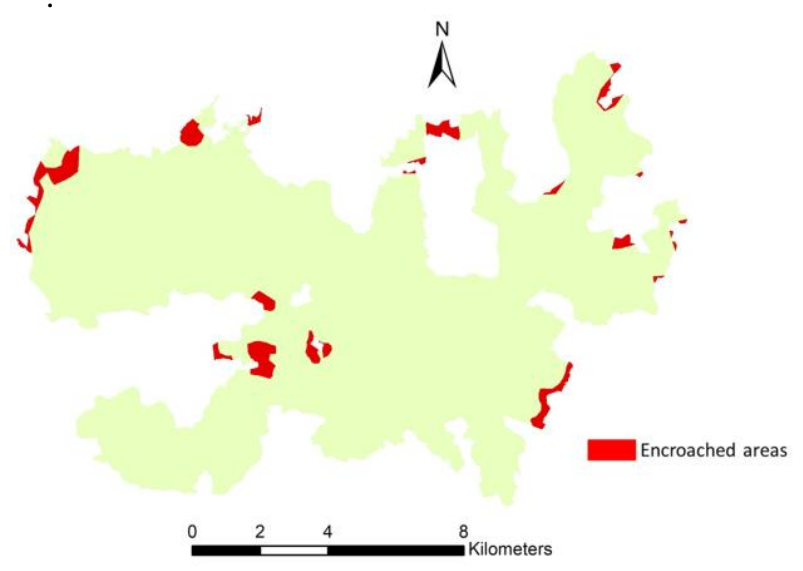

Figure 6. The distribution of forest encroachment inside the MKMPA

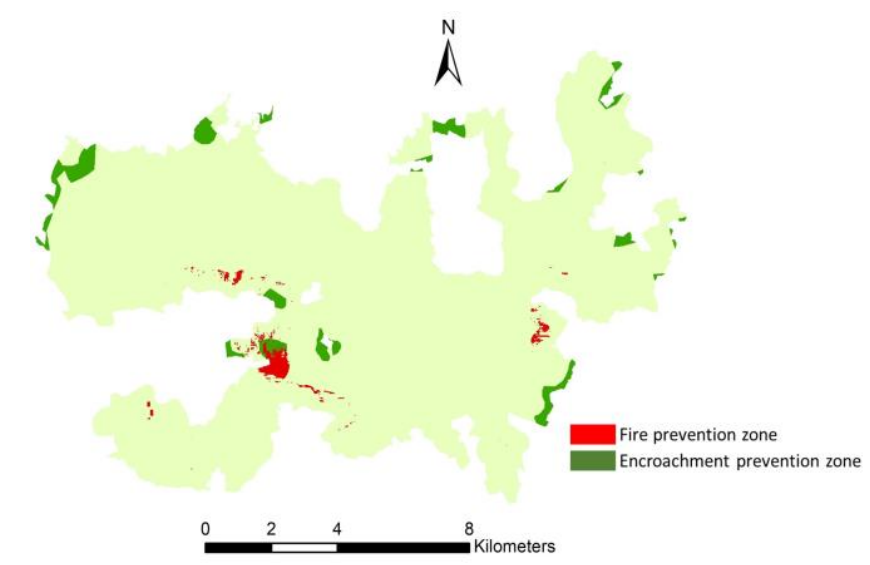

Figure 7. Priority areas for buffer zone development in dealing with fire and encroachment risks 
Table 1. Selected tree species for fire prevention zone development

\begin{tabular}{lll}
\hline \multicolumn{1}{c}{ Tree species } & Local name & \multicolumn{1}{c}{ General characteristics } \\
\hline Albizia procera & Ki Hiyang & Fire-resistant, windbreak, drought tolerant, fast growing, local species \\
Schima wallichii & Puspa & Fire-resistant, dense canopy, evergreen, fast growing \\
Aleurites moluccanus & Kemiri & Windbreak, wide canopy, drought tolerant, fast growing, requiring less \\
& & maintenance, local species \\
Castanopsis acuminatissima & Jarak anak & Evergreen, dense canopy, fast growing, local species \\
Homalanthus populneus & Kareumbi & Evergreen, wide canopy, fast growing, local species \\
Castanopsis argentea & Saninten & Evergreen, climax species, local species \\
Bischofia javanica & Gadog & Fire-resistant, dense canopy, climax species, local species \\
\hline
\end{tabular}

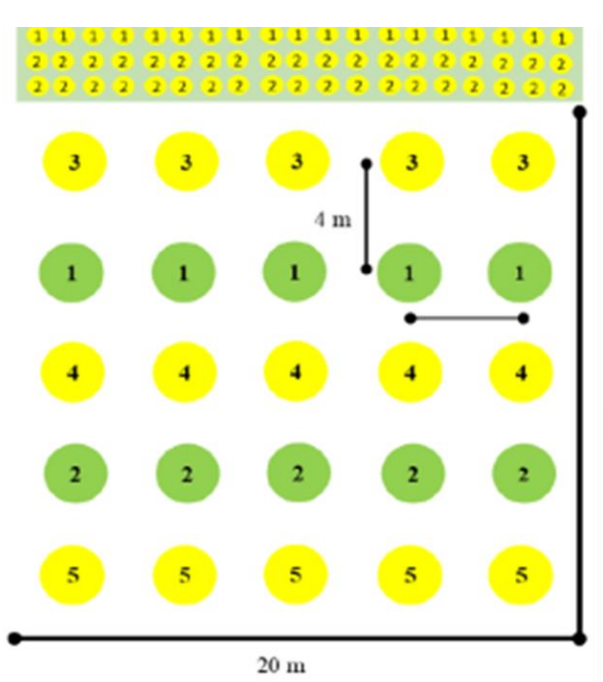

A

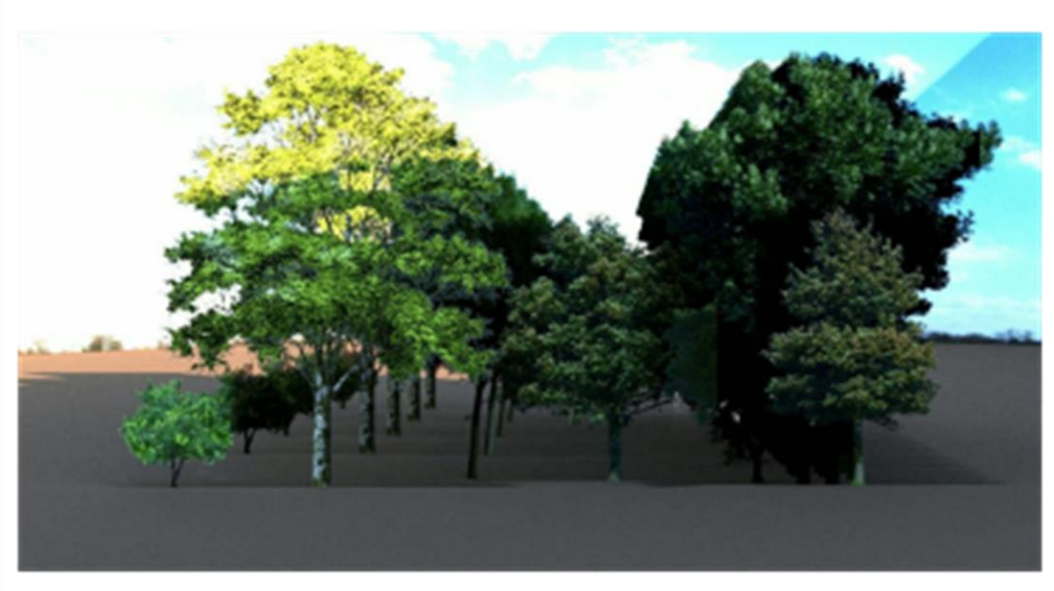

B

Figure 8.A. Design of tree composition and configuration in the fire prevention zone. Yellow circle represents pioneer tree species that consist of: 1. Albizia procera, 2. Schima wallichii, 3. Aleurites moluccanus, 4. Castanopsis acuminatissima, and 5. Homalanthus populneus. Green circle represents climax tree species that consist of: 1. Castanopsis argentea and 2. Bischofia javanica; B. Representative growth of canopy cover after plantation

The design suggests a combination of pioneer and climax tree species, which will be planted alternately. The pioneer trees, which can grow faster, potentially cover the area in a short period. The climax trees, generally shade tolerant in their initial growing period, should be planted once pioneer trees provide enough shade. The existence of the climax, fire-resistant trees is intended to accelerate the ability of the zone to prevent the potential fire spread in the MKMPA forest.

The encroachment prevention zone is designated as a special use zone for local people. In this zone, the need to reforest the deforested areas will be combined with the provision of multiple benefits for local people in the form of non-timber forest products. The main purpose is to promote collaboration between the MKMPA and local people to conserve forest ecosystem and utilize forest ecosystem services. The best scheme for this purpose is development of an agroforestry system.

Agroforestry is a forest system, in which crops are cultivated in between trees or under forest canopy. In support of developing an agroforestry system, the tree species selection may be based on some criteria, including local fast-growing multipurpose tree species (MPTS) with high adaptability, requiring less maintenance and requiring high solar radiation. The criteria for crops include having high economic value, shade tolerant crop, requiring less maintenance and the availability of market. Based on those criteria, this study selected 11 tree and crop species (Table 2) for the development of the encroachment prevention zone.

Table 2 lists four MPTS (Aleurites moluccanus, Artocarpus heterophyllus, Persea americana, and Mangifera indica), two annual crops (Citrus reticulata and Coffea arabica) that potentially produce fruit in shorter time compared to MPTS, and five seasonal crops (Capsicum annuum, Curcuma domestica, Zingiber officinale, Amomum compactum, Ananas comosus). This combination will provide different types of products (nontimber forest products and agricultural products) in different production periods.

The design of tree and crop composition and configuration for the agroforestry system in the encroachment prevention zone, with a sample layout area of $30 \times 30 \mathrm{~m}^{2}$, is presented in Figure 9. 
Table 2. Selected tree and agricultural crop species for encroachment prevention zone development

\begin{tabular}{|c|c|c|}
\hline Tree species & Local name & General characteristics \\
\hline Aleurites moluccanus & Kemiri & $\begin{array}{l}\text { High competitiveness against shrubs and weeds (including Imperata cylindrica), high } \\
\text { selling price }\end{array}$ \\
\hline Artocarpus heterophyllus & Nangka & High competitiveness against shrubs and weeds (including Imperata cylindrica) \\
\hline Persea americana & Alpukat & High selling price, high demand \\
\hline Citrus reticulata & Jeruk keprok & high demand, suitable for highland \\
\hline Mangifera indica & Mangga & High selling price, high demand, high productivity \\
\hline Coffea arabica & Kopi & Shade tolerant, high selling price \\
\hline Capsicum аппиит & Cabai & High selling price, high demand \\
\hline Curcuma domestica & Kunyit & Shade tolerant, less maintenance \\
\hline Zingiber officinale & Jahe & Shade tolerant, less maintenance \\
\hline Amomum compactum & Kapulaga & Shade tolerant, high selling price, less maintenance \\
\hline Ananas comosus & Nanas & Protecting crops from disturbance caused by animal \\
\hline
\end{tabular}
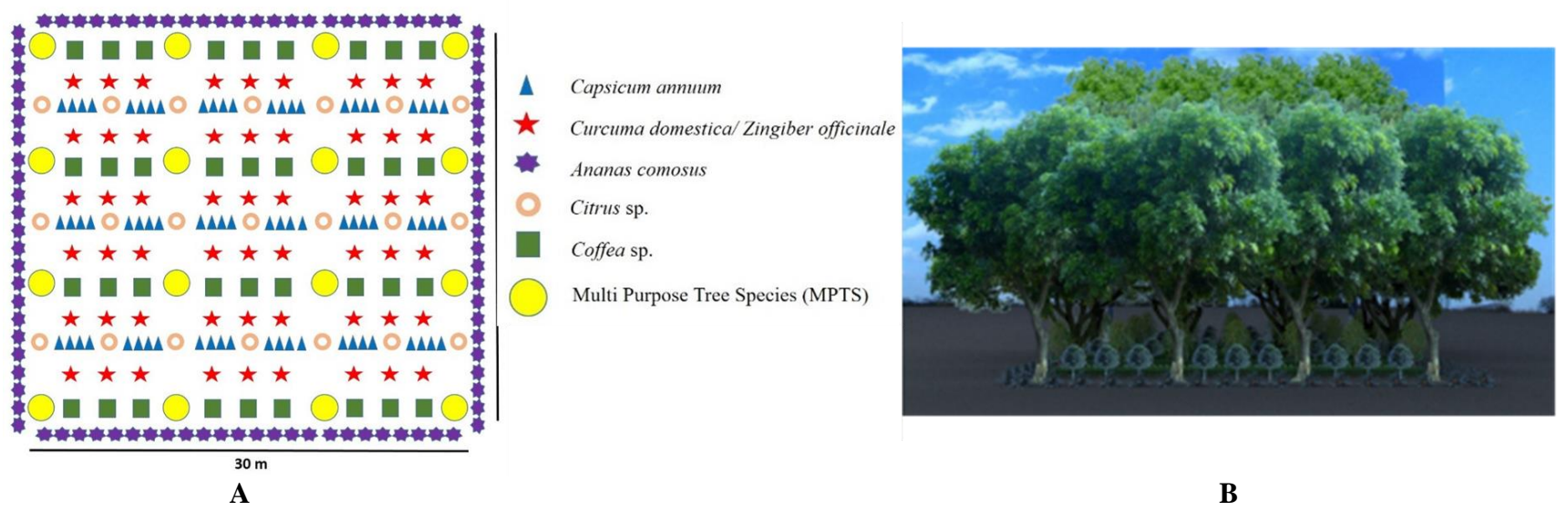

Figure 9. A. Design of tree and crop composition and configuration for the agroforestry system in the encroachment prevention zone; B. Representative growth of canopy cover after plantation

Figure 9 shows that the agroforestry system physically resembles a forest ecosystem. This potentially supports the ecosystem in providing services other than provisioning services (non-timber forest products and agricultural products). The services include hydrological services, carbon sequestration and storage, and habitat for wild animals.

The agroforestry system has been widely promoted as part of protected area management in different countries, with particular purposes to provide economic benefits to local people, alongside conserving local biodiversity (Schroth and da Mota 2013; Mukul and Saha 2017; Riani et al. 2017). However, considering that the encroachment protection zone is inside a protected area, development of an agroforestry system should pay attention to several points, e.g. maintaining the forest status and function, and not granting the land ownership of the encroached areas to the local people. The agroforestry development inside a protected area should also be treated as a transition stage. The best scheme for empowering local people living around a protected area is by involving them in the nonextraction economic activities inside the protected area, particularly in the form of ecotourism and payment for ecosystem services (e.g. carbon sequestration service).
In conclusion, this study demonstrated spatial information of anthropogenic disturbances inside a protected area in selecting and designing area for buffer zone development, with a case study in Masigit Kareumbi Mountain Protected Area (MKMPA), West Java, Indonesia. Two types of anthropogenic disturbances were spatially analyzed, i.e. forest fire and forest encroachment for agricultural practices. The spatial distribution of fire risk in the study area was modeled well using MaxEnt with an AUC of 0.98. This study found that about 109 ha area located in the border of the MKMPA has fire risk of more than 0.5 , and suggested to select these areas as the fire prevention zone. This study proposed the use of seven tree species in the design of the fire protection zone, with the fire-resistant characteristic as the main consideration. This study also identified 428 ha agricultural area inside the MKMPA based on a combination of satellite image (Landsat OLI 8) interpretation and field observation. The agricultural practice inside the MKMPA is considered as illegal, and categorized as an encroachment. This study proposed to select the encroached area as buffer zone, with a specific purpose to prevent further encroachment by developing an agroforestry system. The agroforestry development in this zone was designed to combine reforestation and agricultural practices that are compatible 
with forest ecosystem. This study hence clearly shows a framework of an anthropogenic disturbances-based buffer zone development that can further be implemented for different types of disturbances and different types of protected areas.

\section{ACKNOWLEDGEMENTS}

This research was funded by the Institute for Research and Community Services, Institut Teknologi Bandung, Indonesia.

\section{REFERENCES}

Alexandre B, Crouzeilles R, Grelle CEV. 2010. How can we estimate buffer zones of protected areas? A proposal using biological data. $\begin{array}{lllll}\text { Natureza \& Conservação } 8 & \text { (2): } 165-170 . & \text { DOI: }\end{array}$ 10.4322/natcon.00802010.

Bamford AJ, Ferrol-Schulte D, Wathan J. 2014. Human and wildlife usage of a protected area buffer zone in an area of high immigration. Oryx 48 (4): 504-513. DOI: 10.1017/S0030605313000215.

Bhusal N. 2014. Buffer zone management system in protected areas of Nepal. The Third Pole: J Geogr Educ 11: 34-44. DOI: 10.3126/ttp.v11i0.11558

Brun C, Cook AR, Lee JSH, Wich SA, Koh LP, Carrasco LR. 2015. Analysis of deforestation and protected area effectiveness in Indonesia: A comparison of Bayesian spatial models. Glob Environ Change 31: 285-295. DOI: 10.1016/j.gloenvcha.2015.02.004.

Cleary DFR, DeVantier L. 2019. Indonesia: Threats to the Country's Biodiversity. In: Nriagu JO (eds.). Encyclopedia of Environmental Health (2nd ed.) Elsevier. DOI: 10.1016/B978-0-444-52272-6.005043.

Convention on Biological Diversity. 2021. Indonesia, Main Details. Available at: https://www.cbd.int/countries/profile/?country=id Accessed on 25 May 2021

Decker D. 2001. GIS Data Sources. John Wiley, New York.

Duong TMP, Lobry de Bruyn L, Kristiansen P, Marshall GR, Wilkes J. 2021. Nature and level of NTFP reliance: A case study in the buffer zone of Cat Tien National Park, Vietnam. For Trees Livelihoods 30 (2): 116-132. DOI: 10.1080/14728028.2021.1891976.

Guevara S, Laborde J. 2008. The landscape approach: Designing new reserves for protection of biological and cultural diversity in Latin America. Environ Ethics 30 (3): 251-262. DOI 10.5840/enviroethics200830331.

Indonesian Ministry of Environment and Forestry. 2018. Indonesian Ministry of Environment and Forestry Law No P.20/MENLHK/SETJEN/KUM.1/6/2018

Indonesian Ministry of Environment and Forestry. 2020. Statistics of Directorate General of Natural Resources and Ecosystem Conservation 2019. Jakarta. [Indonesian]

Johnston L, Samadhi TN, Minnemeyer S, Sizer N. 2015. Indonesia's Forest Fires Reignite, Threatening Protected Areas and Peatlands. Available at: https://www.wri.org/insights/indonesias-forest-firesreignite-threatening-protected-areas-and-peatlands Accessed on 27 May 2021
Jotikapukkana S, Berg ̊, Pattanavibool A. 2010. Wildlife and human use of buffer-zone areas in a wildlife sanctuary. Wildlife Res 37 (6): 466474. DOI: 10.1071/WR09132.

Kahler JS. 2018. The situational prevention of wildlife poaching in Bukit Barisan Selatan National Park, Sumatra, Indonesia. [Ph.D. Dissertation]. Michigan State University, Michigan, USA.

Knott CD, Kane EE, Achmad M, Barrow EJ, Bastian ML, Beck J, et al. 2021. The Gunung Palung Orangutan Project: Twenty-five years at the intersection of research and conservation in a critical landscape in Indonesia. Biol Conserv 255: 108856 DOI: 10.1016/j.biocon.2020.108856.

Liu X, Li J. 2008. Scientific solutions for the functional zoning of nature reserves in China. Ecol Model 215 (1-3): 237-246. DOI: 10.1016/j.ecolmodel.2008.02.015

Martin O, Piatti G. 2009. World Heritage and Buffer Zone. UNESCO World Heritage Centre, Paris.

Medrilzam M, Dargusch P, Herbohn J, Smith C. 2013. The socioecological drivers of forest degradation in part of the tropical peatlands of Central Kalimantan, Indonesia. Forestry 87 (2): 335-345. DOI: 10.1093/forestry/cpt033.

Mashapa C, Mhuriro-Mashapa P, Gandiwa E, Muboko N, Chinho T. 2021. The importance of buffer zones in woody vegetation conservation in areas that combine mega-fauna and anthropogenic disturbance: The case of Save Valley landscape, south-eastern Zimbabwe. Glob Ecol Conserv 26: e01503. DOI: 10.1016/j.gecco.2021.e01503.

Nguyen T, Lawler S, Paul W. 2019. Socioeconomic and indigeneity determinants of the consumption of non-timber forest products in Vietnam's Bu Gia Map National Park. Int J Sustain Dev World Ecol 2 6 (7): 646-656. DOI: 10.1080/13504509.2019.1649314.

Mukul SA, Saha N. 2017. Conservation benefits of tropical multifunctional land-uses in and around a forest protected area of Bangladesh. Land 6 (1): 2. DOI: 10.3390/land6010002.

Paolino RM, Versiani NF, Pasqualotto N, Rodrigues TF, Krepschi VG, Chiarello AG. 2016. Buffer zone use by mammals in a Cerrado protected area. Biota Neotrop 16 (2): e20140117. DOI: 10.1590/16760611-BN-2014-0117.

Phillips SJ, Anderson RP, Dudík M, Schapire RE, Blair ME. 2017. Opening the black box: An open-source release of Maxent. Ecography 40: 887-893. DOI: 10.1111/ecog.03049.

Riani WM, Sunkar A, Sundawati L. 2017. The contribution of agroforestry to rural household income at the Grand Forest Park. J Rural Indonesia 3 (1). Available at http://ejournal.skpm.ipb.ac.id/index.php/ruralindonesia/article/view/2 9, accessed on 17 May 2021

Sayer J. 1991. Rainforest Buffer Zone, Guidelines for Protected Area Managers. IUCN Forest Conservation Programme.

Schroth G, da Mota, MSS. 2013. Technical and institutional innovation in agroforestry for protected areas management in the Brazilian Amazon: Opportunities and limitations. Environ Manage 52: 427440. DOI: 10.1007/s00267-013-0049-1.

Siswanto W. 2017. Conservation Area Management in Indonesia: Existing Management, Lessons Learned and Recommendations. Deutsche Gesellschaft für Internationale Zusammenarbeit (GIZ) $\mathrm{GmbH}$ and The Indonesian Ministry of Environment and Forestry, Jakarta.

Sumarga E. 2017. Spatial indicators for human activities may explain the 2015 fire hotspot distribution in Central Kalimantan, Indonesia. Trop Conserv Sci 10: 1-9. DOI: 10.1177/1940082917706168.

Supriatna J, Shekelle M, Fuad HAH, Winarni NL, Dwiyahreni AA, Farid M, et al. 2020. Deforestation on the Indonesian island of Sulawesi and the loss of primate habitat. Glob Ecol Conserv 24: e01205. DOI: 10.1016/j.gecco.2020.e01205 